\title{
AKTIVITAS ANTIINFLAMASI EKSTRAK RIMPANG TEMU KUNCI (Boesenbergia pandurata) SECARA IN-VITRO
}

\author{
Rina Adilla Akmalia*, Hajrah, Laode Rijai \\ Laboratorium Penelitian dan Pengembangan "FARMAKA TROPIS" Fakultas Farmasi \\ Universitas Mulawarman, Samarinda, Kalimantan Timur \\ *email: adillarina@gmail.com
}

\begin{abstract}
ABSTRAK
Inflamasi merupakan suatu respon terhadap rangsangan kimia, mekanik maupun infeksi mikroorganisme. Temu kunci (Boesenbergia pandurata) tersebar luas di Indonesia salah satunya di Kalimantan Timur yang telah dimanfaatkan khasiatnya untuk pengobatan tradisional dan digunakan sebagai salah satu pelengkap bumbu masakan. Kandungan metabolit sekunder utama rimpang temu kunci adalah senyawa golongan flavonoid dan turunannya. Dimana senyawa flavonoid memiliki aktivitas biologi diantaranya sebagai antiinflamasi. Penelitian ini bertujuan untuk mengetahui aktivitas antiinflamasi dan potensi ekstrak etanol rimpang temu kunci (Boesenbergia pandurata) terhadap natrium diklofenak $100 \mu \mathrm{g} / \mathrm{mL}$ secara in vitro menggunakan metode stabilisasi membran sel darah merah manusia (HRBC stabilization). Data pengukuran ekstrak etanol rimpang temu kunci (Boesenbergia pandurata) menunjukkan aktivitas antiinflamasi pada konsentrasi (50, 75, 100, 125 dan 150) $\mu \mathrm{g} / \mathrm{mL}$ masing-masing sebesar 67,39; 78,26; 28,26; 54,35 dan 73,9\% dimana natrium diklofenak mempunyai aktivitas sebesar 76,08\%.
\end{abstract}

Kata Kunci: antiinflamasi, Boesenbergia pandurata, sel darah merah

\begin{abstract}
Inflammation is a response to a chemical stimulus, mechanical or infectious microorganisms. Temu kunci (Boesenbergia pandurata) is widespread in Indonesia. At East Kalimantan this plant have been traditionally used for medicinal properties and as a culinary spice. The secondary metabolites content of temu kunci rhizome is flavonoid compounds and their derivatives. Where flavonoid compounds have biological activity such as anti-inflammatory. This study aims to determine anti-inflammatory activity and the potential from ethanol extract of temu kunci rhizome (Boesenbergia pandurata) against diclofenac sodium $100 \mu \mathrm{g} / \mathrm{mL}$ using in vitro method with human red blood cell membrane stabilization (HRBC stabilization) method. Measurement data from ethanol extract of temu kunci rhizome (Boesenbergia pandurata) demonstrated anti-inflammatory activity at concentrations $(50,75,100,125$ and 150$) \mu \mathrm{g} / \mathrm{mL}$ respectively $67.39 ; 78.26 ; 28.26 ; 54.35$ and $73.9 \%$ where diclofenac sodium has an activity of $76.08 \%$.
\end{abstract}

Keywords : anti-inflammatory, Boesenbergia pandurata, red blood cell 


\section{PENDAHULUAN}

Inflamasi adalah respons terhadap cedera jaringan dan infeksi. Ketika proses inflamasi berlangsung, terjadi reaksi vaskular di mana cairan, elemen-elemen darah, sel darah putih (leukosist), dan mediator kimia berkumpul pada tempat cedera jaringan atau infeksi. Proses inflamasi merupakan suatu mekanisme perlindungan di mana tubuh berusaha untuk menetralisir dan membasmi agen-agen yang berbahaya pada tempat cedera dan untuk mempersiapkan keadaan untuk perbaikan jaringan. Tanda-tanda dari proses inflamasi antara lain adalah rubor (kemerahan), kalor (panas), tumor (pembengkakan), dolor (nyeri), dan function laesa (perubahan fungsi).

Bermacam-macam obat yang digunakan untuk mengatasi peradangan. Antiinflamasi golongan steroid dan non steroid misalnya berbahaya bila digunakan secara tidak tepat, penggunaan jangka panjang menyebabkan efek samping yang cukup berat. Adapun obat antiinflamasi golongan non steroid dapat menyebabkan retensi cairan, hipertensi edema, nyeri perut, displasia, mual, muntah hingga ulser atau pendarahan.

Salah satu tanaman tradisonal yaitu Boesenbergia pandurata (Roxb.) Schlecht atau dikenal dengan nama temu kunci secara empiris digunakan sebagai peluruh dahak, peluruh kentut, penambah nafsu makan, menyembuhkan sariawan, dan pemacu keluarnya air susu ibu (ASI), antibakteri, afrodisiaka, disentri, kolik, antiinflamasi, detoksi pasca melahirkan. Pada penelitian dilaporkan bahwa ekstrak etanolik $B$. pandurata tidak menunjukkan efek toksik.

Rimpang temu kunci mengandung minyak atsiri yaitu metilsinamat, kamper, sineol, dan terpena. Di samping minyak atsiri, temu kunci mengandung saponin dan flavonoid. Flavonoid mempengaruhi berbagai macam aktivitas biologi atau farmakologi, diantaranya antioksidan, antitumor, antiangiogenik, antiinflamasi, antialergik dan antiviral. Selain itu, dilaporkan bahwa golongan senyawa flavonoid memiliki kemampuan dalam menstabilkan membran. Berdasarkan hal tersebut, maka penelitian ini perlu dilakukan untuk mengetahui potensi Boesenbergia pandurata (Roxb.) Schlecht sebagai obat antiinflamasi dengan menggunakan metode stabilisasi membran sel darah merah.

\section{METODE PENELITIAN}

\section{Alat dan bahan}

Alat-alat yang digunakan dalam penelitian ini adalah autoklaf, centrifuge, desikator, inkubator, neraca analitik, rotary vacuum evaporator, spektrofotometer UV-visible.

Bahan-bahan yang digunakan dalam penelitian ini adalah rimpang temu kunci (Boesenbergia pandurata), akuades, buffer posfat $0,15 \mathrm{M}(\mathrm{pH} 7,4)$, darah $(10 \% \mathrm{v} / \mathrm{v}$ suspensi sel darah merah), etanol $96 \%$, larutan isotonis $(0,85 \% \mathrm{w} / \mathrm{v} \mathrm{NaCl})$, larutan hipotonis $(0,25 \%$ w/v NaCl), natrium diklofenak (100 $\mu \mathrm{g} / \mathrm{mL})$.

\section{Metode}

Penelitian diawali dengan mengekstrak rimpang temu kunci $B$. pandurata yang diperoleh di wilayah Samarinda, Kalimantan Timur sebanyak $3 \mathrm{~kg}$. Tahapan dari proses ekstraksi yaitu sortasi, mencuci, memotong-motong rimpang kemudian dikeringkan, simplisia kering yang diperoleh sebanyak $937 \mathrm{~g}$ dimaserasi dengan pelarut etanol selama 2x24 jam dan dipisahkan antara filtrat dan residunya kemudian residu direndam kembali dengan etanol dan dilakukan berulang kali hingga warna maserat bening. Filtrat kemudian dievaporasi menggunakan rotary evaporator pada suhu $55-60^{\circ} \mathrm{C}$, hingga diperoleh ekstrak kasar rimpang temu kunci B. pandurata.

Selanjutnya dilakukan preparasi sampel, yaitu preparasi suspensi $(10 \% \mathrm{v} / \mathrm{v})$ sel darah merah. Sampel darah dimasukkan ke dalam tabung sentrifugasi yang telah berisi larutan 
EDTA, kemudian disentrifugasi dengan kecepatan $3.000 \mathrm{rpm}$ selama 10 menit pada suhu ruang. Supernatan yang terbentuk dipisahkan dengan hati-hati dari sel darah merah menggunakan pipet tetes steril. Endapan sel-sel darah dicuci dengan larutan isosaline dan disentrifugasi kembali. Proses pencucian dan sentrifugasi dilakukan pengulangan sebanyak 5 kali sampai supernatan jernih. Volume sel darah merah diukur dan diresuspensi dengan larutan isosaline sehingga diperoleh konsentrasi suspensi sel darah merah $10 \% \mathrm{v} / \mathrm{v}$.

Kemudian pengujian aktivitas, yaitu dilakukan uji aktivitas antiinflamasi secara in-vitro dengan menggunakan metode stabilisasi membran sel darah merah dan dibandingkan dengan larutan standar (natrium diklofenak $100 \mu \mathrm{g} / \mathrm{mL}$ ). Campuran uji terdiri dari 1,0 mL sampel uji dan larutan standar; 1,0 $\mathrm{mL} 0,15 \mathrm{M}$ buffer posfat ( $\mathrm{pH} 7,4) ; 2 \mathrm{~mL}$ hipotonik saline; dan $0,5 \mathrm{~mL}(10 \% \mathrm{v} / \mathrm{v})$ suspensi sel darah merah. Campuran uji diinkubasi pada suhu $37^{\circ} \mathrm{C}$ selama 30 menit, dan kemudian larutan disentrifugasi pada kecepatan 5000 rpm selama 10 menit. Absorbansi larutan diukur pada panjang gelombang $576.6 \mathrm{~nm}$. Persentase inhibisi hemolisis dihitung dengan menggunakan rumus :

$\%$ inhibisi hemolisis $=100 \% \times \frac{\mathrm{A} 1-\mathrm{A} 2}{\mathrm{~A} 1}$

Dimana: $\mathrm{A} 1=$ Absorbansi larutan kontrol uji

A2 = Absorbansi larutan uji/ larutan standar uji

\section{HASIL DAN PEMBAHASAN}

\section{Uji Aktivitas Antiinflamasi}

Stabilisasi dari membran sel darah merah digunakan sebagai metode untuk mengetahui aktivitas antiinflamasi secara in-vitro. Hal ini dikarenakan membran sel darah merah mirip dengan membran lisosom yang dapat mempengaruhi proses inflamasi sehingga stabilitas lisosom penting dalam membatasi respon inflamasi dengan menghambat pelepasan konstituen lisosomal dari neutrofil aktif seperti enzim bakterisida dan protease, yang menyebabkan peradangan dan kerusakan jaringan lebih lanjut atas extra cellular release, dengan demikian, stabilisasi membran sel darah merah yang diinduksi dengan larutan hipotonik dapat digunakan sebagai ukuran untuk mengindikasikan stabilisasi dari membran lisosom.

Tabel 1. Persen Inhibisi B. pandurata dan Standar Natrium Diklofenak

\begin{tabular}{ccc}
\hline Ekstrak & Konsentrasi $(\mu \mathrm{g} / \mathrm{mL})$ & Inhibisi Hemolisis $(\%)$ \\
\hline Boesenbergia pandurata & 50 & 67,39 \\
& 75 & 78,26 \\
& 100 & 28,26 \\
& 125 & 54,35 \\
Natrium Diklofenak & 150 & 73,9 \\
& 100 & 76,08 \\
\hline
\end{tabular}

Stabilitas membran sel darah merah dari ekstrak rimpang B. pandurata dan natrium diklofenak $100 \mu \mathrm{g} / \mathrm{mL}$ ditunjukkan pada (Tabel 1). Sampel uji yang memiliki aktivitas antiinflamasi dilihat dari penurunan absorbansi hemoglobin yang terdeteksi pada campuran 
larutan uji, yaitu semakin kecilnya serapan yang terdeteksi pada campuran larutan uji berarti membran sel darah merah semakin stabil dan sedikit mengalami lisis. Setelah pengukuran dan diperoleh data absorbansi kemudian dihitung persen inhibisinya. Persen inhibisi adalah kemampuan suatu sampel untuk menstabilisasi sel darah merah yang didapat dari perbandingan serapan antara serapan (absorbansi kontrol dikurangi absorbansi larutan uji) dengan absorbansi kontrol.

Ekstrak B. pandurata memberikan stabilitas membran sel darah merah pada setiap variasi konsentrasi. Semakin kecilnya serapan yang terdeteksi pada campuran larutan uji, berarti membran sel darah merah semakin stabil dan sedikit mengalami lisis. Hasil pengujian menunjukkan bahwa konsentrasi terbesar dalam stabilisasi membran sel darah merah atau inhibisi terjadinya hemolisis pada konsentrasi $75 \mu \mathrm{g} / \mathrm{mL}$ yaitu $78,26 \%$ dibandingkan terhadap natrium diklofenak $100 \mu \mathrm{g} / \mathrm{mL}$ sebesar 76,08\%.

Rimpang temu kunci mengandung minyak atsiri yaitu metilsinamat, kamper,

sineol, dan terpena. Di samping minyak atsiri, temu kunci mengandung saponin dan flavonoid. Beberapa penelitian mengungkapkan bahwa ada hubungan antara kemampuan senyawa flavonoid dalam menstabilkan membran dan sebagai penghambat proses enzimatis selama inflamasi. Hasil penelitian Muralidhar et al (2010) menunjukkan bahwa flavonoid yang diisolasi dari kulit batang Butea monosperma, yaitu Genistein (4',5,7-trihydroxy isoflavone) dan Prunetine (4',5-dihydroxy-7-methoxy isoflavone) memiliki kemampuan menghambat kerja enzim siklooksigenase dan lipooksigenase dalam mengkonversi asam arakidonat menjadi prostaglandin dan leukotrien yang merupakan mediator inflamasi.

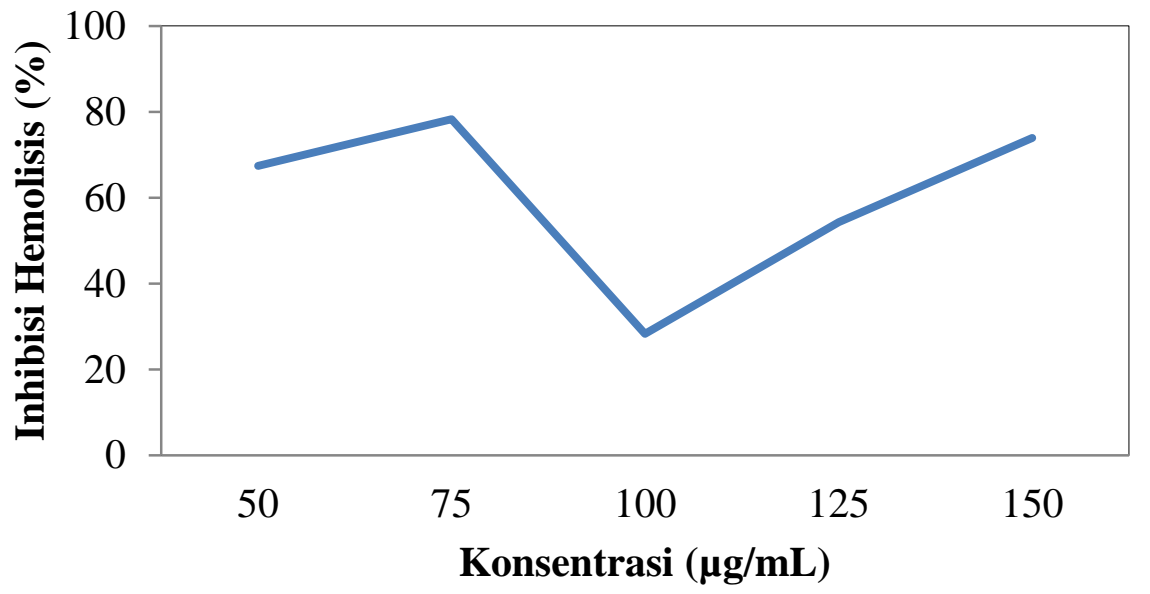

Gambar 1. Kurva Stabilisasi Membran Eritrosit dari esktrak B. pandurata

Hasil tersebut menunjukkan bahwa peningkatan konsentrasi ekstrak pada konsentrasi $50 \mu \mathrm{g} / \mathrm{mL}$ menjadi $75 \mu \mathrm{g} / \mathrm{mL}$ juga meningkatkan persentase inhibisi hemolisis, namun saat konsentrasi kembali ditingkatkan terjadi penurunan aktivitas, yang dapat menunjukkan bahwa ekstrak berada pada titik jenuhnya, kemudian ekstrak mengalami peningkatan kembali, hal ini diduga karena penggunaan ekstrak uji yang konsentrasinya semakin meningkat memiliki nilai absorbansi saat diukur menggunakan panjang gelombang 576,6 nm yang digunakan untuk mengukur absorbansi dari hemoglobin.

Mekanisme kerja dari ekstrak dan obat anti-inflamasi standar diduga berhubungan dengan pengikatan pada membran eritrosit yang selanjutnya membuat perubahan pada muatan permukaan dari sel. Hal ini memungkinkan pencegahan interaksi fisik dengan menggabungkan agen atau mempromosikan penyebaran reaksi tolak-menolak muatan 
seperti yang terjadi dalam hemolisis sel darah merah. Telah dilaporkan bahwa saponin dan flavonoid tertentu memberikan efek menstabilkan pada membran lisosom baik secara in vivo dan in vitro, sedangkan tanin dan saponin memiliki kemampuan untuk mengikat kation, sehingga menstabilkan membran eritrosit dan makromolekul biologi lainnya.

\section{KESIMPULAN}

Ekstrak etanol rimpang temu kunci (Boesenbergia pandurata) memiliki aktivitas antiinflamasi pada berbagai variasi konsentrasi $(50,75,100,125$ dan $150 \mu \mathrm{g} / \mathrm{mL})$ masingmasing sebesar 67,$39 ; 78,26 ; 28,26 ; 54,35$ dan 73,9\%. Ekstrak rimpang B. pandurata berpotensi sebagai obat antiinflamasi. Dimana pada konsentrasi 50 dan $75 \mu \mathrm{g} / \mathrm{mL}$ ekstrak memiliki kemampuan lebih baik dalam menginnhibisi terjadinya hemolisis dibandingkan dengan larutan standar natrium diklofenak $100 \mu \mathrm{g} / \mathrm{mL}$.

\section{DAFTAR PUSTAKA}

Kee, Joyce L dan Hayes E. R. 1996. Farmakologi: Pendekatan Proses Keperawatan. Penerbit Buku kedokteran ECG. Jakarta.

Tanu, I., Syarif, A., Estuningtyas, A. Setiawati, A., Muchtar, H.A., dan Arif, A., 2002, Farmakologi dan Terapi, Fakultas Kedokteran Universitas Indonesia, Jakarta.

Katzung, Bertram G., Masters, Susan B., 2012. Basic and Clinical Pharmacology 12th Edition. McGraw Hill. New York.

Ismawan, B. 2010. Herbal Indonesia Berkhasiat Bukti Ilmiah dan Cara Racik Volume 8. Trubus Swadaya. Bogor.

Saraithong, P., Saenphet, S., Saenphet, K. 2010. Save Evaluation of Ethanol Extract from Boesenbergia rotunda (L) Mansf. in Rats. Trends Research and Technology, 2(1).

Syamsuhidayat, S.S., dan Hutapea, J.R. 1991. Inventaris Tanaman Obat Indonesia Edisi I. Badan Penelitian dan Pengembangan Kesehatan Departemen Kesehatan Republik Indonesia. Jakarta.

Kasolo, JN., Bimeya, GS., Ojok, L., Ochieng, J., Okwal-okeng, JW. 2010. Phytochemicals and Uses of Moringa oleifera Leaves in Ugandan Rural Communities. Journal of Medical Plant Research,4(9): 753-757.

Middleton, E.JR., Kandaswami, C., and Theoharides, T. C., 2000, The Effect of Plant Flavonoids on Mammalian Cells: Implications for Inflammation, Heart Disease, and Cancer, The American Society for Pharmacology and Experimental Therapeutics, 52(4): 673-751.

Oyedapo OO, BA Akinpelu, KF Akinwunmi, MO Adeyinka and FO Sipeolu. 2010. Red blood cell membrane stabilizing potentials of extracts of Lantana camara and its fractions. International Journal of Plant Physiology and Biochemistry. 2(4); 46-51

Leelaprakash, G., and Dass, S.M., 2011, In-vitro Antiinflamatory Activity of Methanol Extract of Enicostemma axillare, International Journal of Drug Development and Research, 3(3): 189-196.

Kumar S. \& Vivek KR. 2011. InVitro AntiArthritic Activity Of Isolated Fractions From Methanolic Extract Of Asystasia dalzelliana Leaves. Asian Journal of Pharmaceutical and Clinical Research, 4(3); 5253.

Manivannana, R., and Sukumar, D., 2007, The RBC Membrane Stabilisation in an In Vitro Method by the Drug Isolated from Lucas aspera, International Journal of Applied Science and Engeneering, 5(2): 133-138.

Lutfiana, 2013, Uji Aktivitas Antiinflamasi Ekstrak Daun Kelor (Moringa oleifera Lam.) dengan Metode Stabilisasi Membran Sel Darah Merah Secara In Vitro, Universitas Islam Negeri, Jakarta. 
Syamsuhidayat, S.S., dan Hutapea, J.R. 1991. Inventaris Tanaman Obat Indonesia Edisi I. Badan Penelitian dan Pengembangan Kesehatan Departemen Kesehatan Republik Indonesia. Jakarta.

Wiranto, E., Wibowo, M.A., dan Ardiningsih, Puji. 2016. Aktivitas Antiinflamasi secara InVitro Ekstrak Teripang Butoh Keling (Holothuria leucospilota Brandt) dari Pulau Lemukutan. JKK, Volume 5(1), 52-57 